Article

\title{
Living and Dead Aboveground Biomass in Mediterranean Forests: Evidence of Old-Growth Traits in a Quercus pubescens Willd. s.l. Stand
}

\author{
Emilio Badalamenti, Tommaso La Mantia *, Giovanni La Mantia, Antonino Cairone and \\ Donato Salvatore La Mela Veca \\ Department of Agricultural, Food and Forest Sciences, University of Palermo, Viale delle Scienze Ed. 4, \\ I-90128 Palermo, Italy; emilio.badalamenti@unipa.it (E.B.); giovannilamantia@gmail.com (G.L.M.); \\ nininho8@hotmail.it (A.C.); donato.lamelaveca@unipa.it (D.S.L.M.V.) \\ * Correspondence: tommaso.lamantia@unipa.it; Tel.: +39-0912-386-1240
}

Academic Editors: Phillip G. Comeau and Timothy A. Martin

Received: 12 April 2017; Accepted: 20 May 2017; Published: 30 May 2017

\begin{abstract}
For a long time, human impact has deeply simplified most of the forest ecosystems of the Mediterranean Basin. Here, forests have seldom had the chance to naturally develop a complex and multilayered structure, to host large and old trees and rich biological communities, approaching old-growth conditions. Also for this reason, limited information is currently available about Mediterranean old-growth forests, particularly with regard to deadwood. The main aim of this work is to help fill this critical knowledge gap. In Sicily (Italy), we identified a Quercus pubescens forest that seemed to show some typical old-growth features. Total living volume $\left(360 \mathrm{~m}^{3} \mathrm{ha}^{-1}\right)$ and basal area $\left(34 \mathrm{~m}^{2} \mathrm{ha}^{-1}\right)$ were, respectively, about 6 and 3 times higher than the averages recorded in the regional forest inventory for this forest type. Deadwood was particularly abundant, exceeding the threshold of $30 \mathrm{~m}^{3} \mathrm{ha}^{-1}$, mainly represented by lying dead elements. Dead to live wood ratio reached $9 \%$, a value close to the threshold of $10 \%$ considered for Mediterranean old-growth forests. As the investigated forest showed some typical old-growth traits, it deserves to be fully protected and could be a permanent monitoring area for studying deadwood and stand dynamics in mature Mediterranean stands.
\end{abstract}

Keywords: mature forests; deadwood; downy oak; Quercus ilex; Acer campestre

\section{Introduction}

Interest in and attention to old-growth forests have grown considerably in Europe in recent decades [1]. Compared to the remaining primary forests, which are estimated to occupy only $4 \%$ of the total European forest area, excluding the Russian Federation [2], old-growth forests show a physiognomy still affected by former anthropogenic management [3]. When a forest stand has had the chance to develop and mature for a sufficient period of time in the almost-total absence of human interference, it tends to reach physiognomic, structural, and compositional traits very different from those of similar forest types that are not sufficiently aged or are still managed and/or largely disturbed by humans [4]. Under certain circumstances, natural development may allow the establishment of structurally complex, biologically rich, resilient, and stable forest stands, while in other cases, some form of forest management seems to be required to facilitate the achievement of such conditions [5]. This is particularly the case of Mediterranean forests. However, it should be kept in mind that not all old-growth forests are species rich and complex, as also monospecific forest stands with only one dominant tree layer may originate old-growth stands.

Old-growth forests play a major and well-recognised role in conservation of biological diversity, soil protection, and mitigation of climate change by means of $\mathrm{C}$ sequestration in long-term pools, 
as well as watershed supply and water quality [6-8]. Many living organisms exclusively owe their survival to complex, mature, and relatively undisturbed (by humans) forest ecosystems, which are worthy to be fully preserved. However, to accomplish this, such forest stands need to be identified and characterised.

There is no universally-accepted definition of old-growth forest. Instead, some selected biological and structural parameters are commonly used as proxy indicators for old-growth conditions. For instance, in temperate ecosystems all around the world, despite large climatic and compositional differences, densities of large living trees, quadratic mean diameter, amount of living aboveground biomass, and coarse woody debris are found to be significantly higher in old-growth forest stands [9]. Accordingly, the occurrence of senescent and/or large trees, the amount of deadwood, and, consequently, the absence of significant and recent signs of human disturbance are considered the most reliable proxy of mature forest stands, tending toward old-growth conditions [3]. Particularly, deadwood is among the major diagnostic features that have to be taken into account for the identification and characterisation of an old-growth forest because it provides indirect information about forest ageing, human disturbance, as well as living organisms [10].

The formation of deadwood in a forest depends on the frequency, intensity, and scale of disturbances, such as wind, snow, drought, pests, and wildfires, which may determine the falling of branches or twigs and/or the death of whole trees [11]. Hence, natural disturbance represents the main input of deadwood in a forest ecosystem, and this seems to be a rather general pattern. However, in the Mediterranean basin, the chance of effective accumulation and maintenance in time of deadwood is largely a consequence of the abandonment of forest management, as deadwood removal was one the most common silvicultural practices. It has been therefore the cessation of logging the major driving factor allowing deadwood accumulation and diversification within Mediterranean forests. The amount of deadwood in a forest is influenced by many interacting factors; among them, the dominant tree species, aboveground living biomass, and the time elapsed since the last harvest seem to play a major role $[2,12]$.

Deadwood plays an essential role in the functioning of forest ecosystems and the maintenance of biodiversity. It is at the base of the detrital food chain and the key site of many biological activities, allowing the differentiation of many potentially-available ecological niches [13]. Deadwood is the main and/or exclusive habitat for a broad range of living organisms that, in turn, may feed other important wild animal species, so that all ecosystem food chains are enriched. The more diversified and abundant the deadwood is, the higher the biodiversity of organisms that a forest stand can potentially host. Both the quantitative and qualitative aspects are of great importance for the conservation of a wide array of different taxonomic groups. Apart from a quantitative assessment, deadwood has to be characterised in qualitative terms, including the type, size and decay class of dead elements, the tree species, the cause of death of the plant, and spatialdistribution [14]. Standing dead trees are used by some birds as nesting sites, while cavities are directly made by woodpeckers such as Dendrocopos major Linnaeus 1758 for shelter and safe places to feed on larvae of saproxylic insects [15]. Lying deadwood is used as habitat by reptiles, amphibians, and small mammals, as a food source or shelter. Insects are particularly linked to deadwood, as they are, together with soil fungi, the main organisms responsible for the decomposition and mineralisation of organic matter on the forest floor, thus allowing the recirculation of mineral nutrients fixed in woody biomass [16]. In Europe, forest management generally exerted a negative effect on biodiversity of substrate-dependent taxonomic groups, such as mosses, lichens, and saproxylic beetles [17]. Even many bird species have been strongly affected by the alteration and the simplification of European forest ecosystems [18,19].

Last but not least, deadwood plays a key role in nutrient recycling, the enhancement of C stock, the improvement of soil fertility, protection, and biological activity [20], with clear positive effects on slope stability [21]. For these reasons and many others, deadwood has been included among the Pan-European indicators of Sustainable Forest Management (SFM), particularly under Criterion 4, concerning "Maintenance, conservation and appropriate enhancement of biological diversity in 
forest ecosystems" [2,22], and it is widely considered a key parameter to assess and monitor the overall status of a forest ecosystem, as it is strongly affected by forest ageing and human disturbance, as well as living organisms [10,23].

Despite the increasing attention of research to this topic, both at the national and European level, in the Mediterranean knowledge is still limited about the amount and the variation over time of deadwood within many forest types, especially those dominated by thermophilic Quercus spp. [24,25]. In contrast, extensive research and much more detailed information is available for the forests and tree species of Central and Northern Europe. Making up for this lack of knowledge is crucial if we are to ensure long-term protection of these valuable ecosystems, as has been emphasised in a recent report on the state of European forests [22], and further confirmed by Paletto et al. [25], who stated: "Deadwood has not been extensively investigated in Mediterranean-oak ecosystems...".

We aimed at filling this gap of knowledge about deadwood and old-growth forests in Mediterranean ecosystems. It is the necessary starting point if we are to ensure effective protection to so important forest stands. Our research has been carried out within a Mediterranean Quercus pubescens Willd s.l. (Downy oak) stand, suspected to hold old-growth traits [26]. Our main hypothesis is that aboveground traits of this forest, both living and dead, fall within the values reported in literature concerning Mediterranean old-growth forests. We hypothesize that deadwood amount could approach $30 \mathrm{~m}^{3} \mathrm{ha}^{-1}$, the most commonly considered threshold, that deadwood lying on the ground is prevalent, and that dead to live wood ratio could be close to $10 \%$, the reference value for Mediterranean old-growth forests. We have also assessed the contribution of coarse deadwood (diameter $>30 \mathrm{~cm}$ ) to standing, lying and total deadwood for its recognized role to enhance biological diversity of forests. If these hypotheses were confirmed, similar forest stands could be relatively more frequent than expected in the Mediterranean. At last, the current research should be used for future development of specific guidelines for the identification and management of old-growth Mediterranean forests.

\section{Materials and Methods}

\subsection{Study Area and Vegetation}

The study area is located on the island of Sicily (Italy), within the Nature Reserve "Bosco della Ficuzza, Rocca Busambra, Bosco del Cappelliere e Gorgo del Drago", as classified according to the regional legislation about protected areas. It consists of a large protected area, covering more than 7000 ha. The experimental 1-ha plot is located within zone A of the Reserve, in Contrada Fanuso (Municipality of Godrano, Palermo Province; Figure 1). The plot lies at a mean altitude of $1000 \mathrm{~m}$ and falls within the mesomediterranean upper sub-humid bioclimatic belt [27]. Mean annual precipitation is $752 \mathrm{~mm}$ while mean annual temperature is $15.1^{\circ} \mathrm{C}$, with a mean maximum temperature of $20.5^{\circ} \mathrm{C}$ and a mean minimum temperature of $9.8^{\circ} \mathrm{C}$ [28]. Soils at the base of the northern slopes of Rocca Busambra are predominantly sandy loam; they are deep and developed enough to be well-suited to supporting tree vegetation [29].

The considerable climatic and altitude variability that characterises the whole Nature Reserve has played a major role in driving biodiversity patterns and structural traits of local forest ecosystems. The reserve consists of a mosaic of natural, seminatural, and synanthropic vegetation [30], due to the interpolation of afforestation interventions into the natural evolution of the forest, including continuous grazing, which is still one of the most critical aspects of forest management in Sicily and has to be particularly considered. 


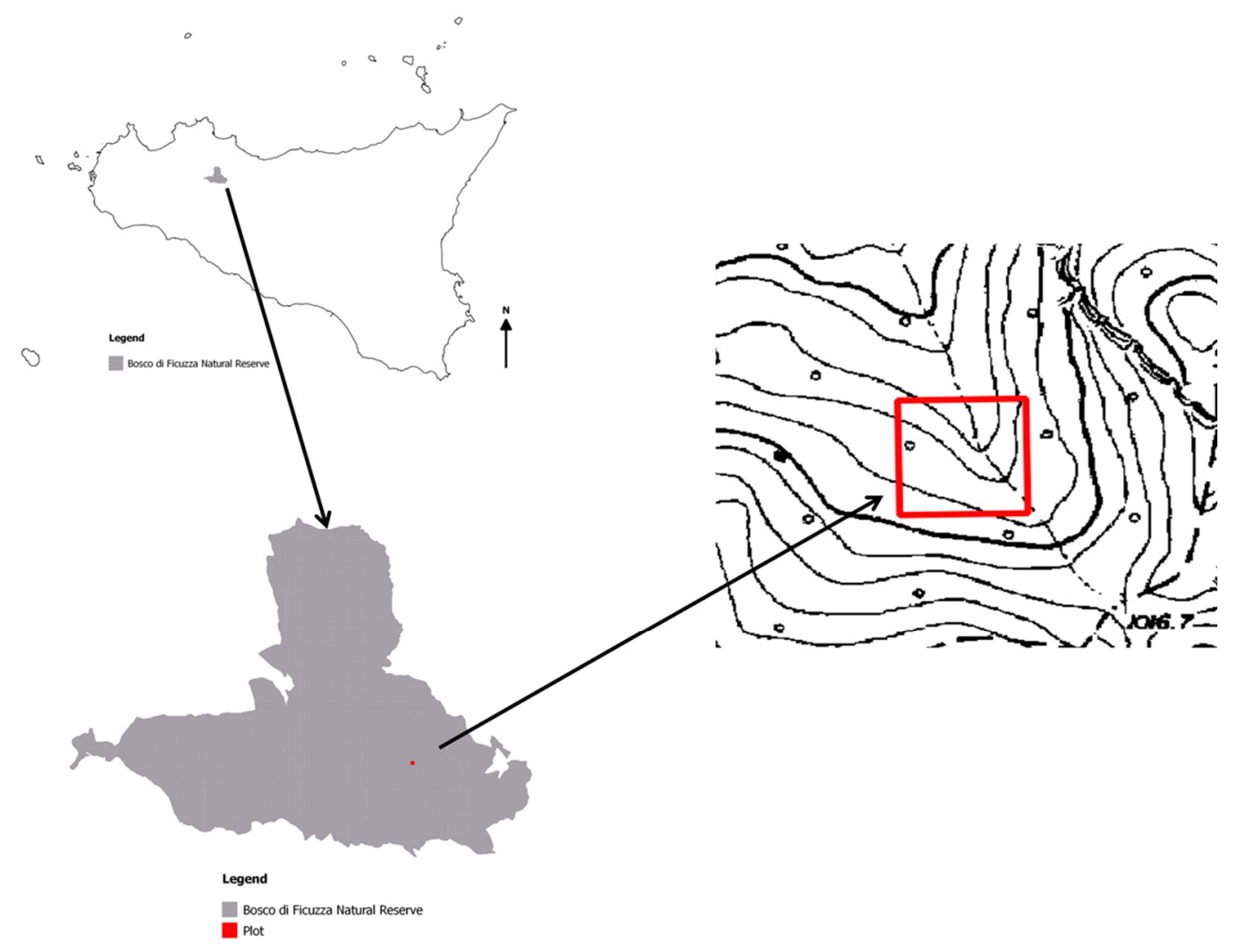

Figure 1. Location of the Reserve within which the experimental plot was established. On the right a detail of the Technical Map of Sicily in 1:10,000 scale.

The natural woody vegetation mainly consists of thermo-mesophilous deciduous oak forests, including species such as Quercus pubescens and Quercus gussonei (Borzi) Brullo [31,32] together with the evergreen thermophilous oaks Quercus ilex L. (Holm oak) and Quercus suber L. [33]. Other tree species present are Fraxinus ornus L. (Manna ash), Acer campestre L. (Field maple), Sorbus torminalis L. Crantz, Mespilus germanica L. (Common medlar), and Malus sylvestris Mill. [30], including two recently found and uncommon woody species such as Ostrya carpinifolia Scop. and Quercus trojana Webb subsp. trojana [34,35].

Our survey was carried out within a forest stand dominated by Quercus pubescens, Quercus ilex, and Acer campestre. The dominant trees generally reach full canopy cover but in some areas the forest cover is interrupted by several fallen trees. The presence of such gaps is a notable element for the structural diversification of the forest, which enhances its biological diversity and presents a chance for heliophilous tree species to regenerate [36]. The choice of this area to characterise deadwood was made taking into account the main attributes that are generally considered to be the most useful proxy indicators of old-growth conditions: the occurrence of large and/or old trees, a complex forest structure, a significant amount of deadwood either standing or lying on the ground, a very high overall level of biodiversity, and the absence of recent human disturbance especially in terms of harvest or wildfire [26].

\subsection{Sampling Protocol}

The sampling design used in the experimental area to detect forest attributes followed the standard procedure adopted under the project PRIN 2007, "Innovative methods for the identification, characterization and management of old-growth forests in the Mediterranean environment" (e.g., [37]). The experimental area constitutes a square plot of $100 \times 100 \mathrm{~m}$ (total area of about 1 hectare), with sides perpendicularly oriented to the cardinal directions N-S and E-W (Figure 2). 


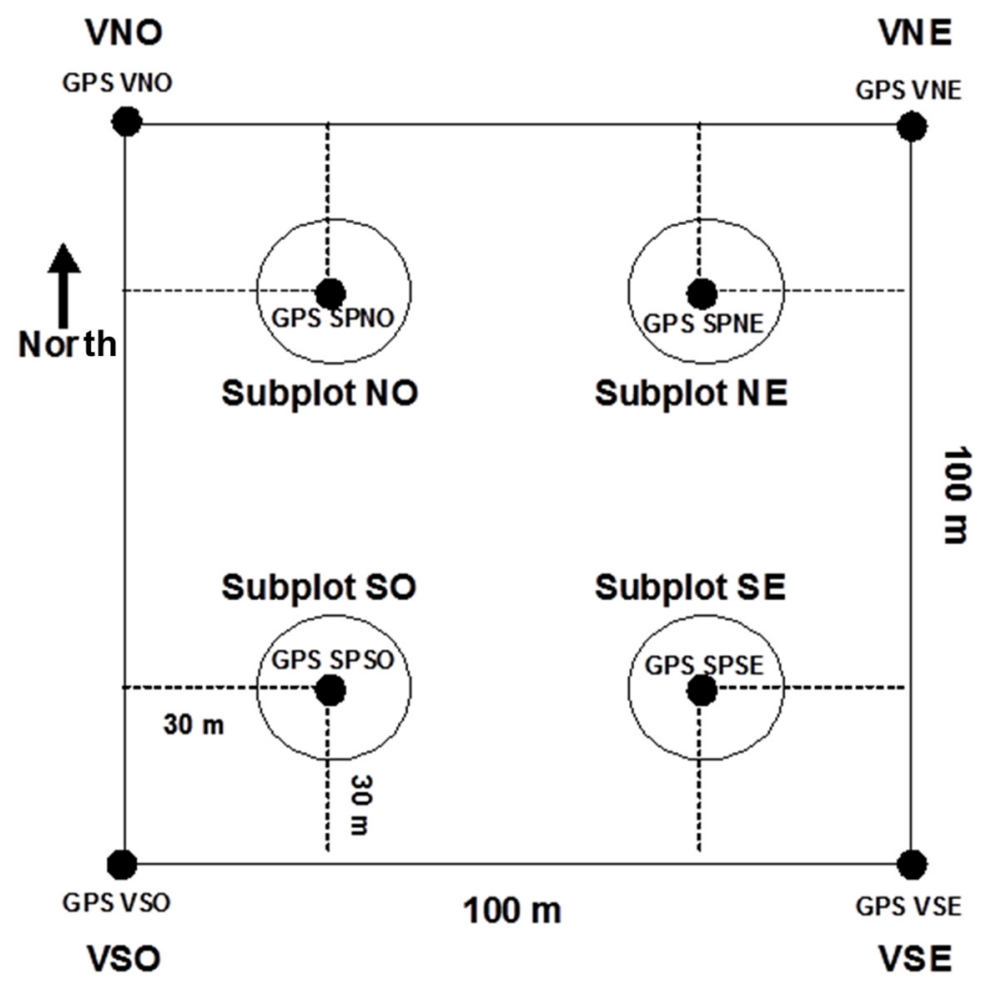

Figure 2. Sampling design of the experimental plot on the Nature Reserve.

After the preliminary phase of inspections and identification on the map, the experimental area needed to be materialised in the field. After the first vertex had been established, its coordinates were used to automatically get the coordinates of the other three vertices. Then, all the vertices were retraced in the field by means of GPS (Trimble ${ }^{\circledR}$ GeoXH 2008, Sunnyvale, CA, USA), and were materialised with Castanea sativa Mill. (Sweet chestnut) poles sprayed with red varnish to facilitate the subsequent recognition and monitoring activities. For each vertex, the geographical coordinates within the cartographic reference system UTM, zone 33N, datum WGS84, were acquired. To acquire positions with GPS, at least 200 positions per each point were taken. In addition to the four vertices (VNO, VNE, VSE and VSO), eight other points, including four intermediate with respect to the vertices (CF1, CF2, CF3 and CF4), were also identified and acquired. The other four georeferenced points (SPSE, SPNE, SPNO and SPSO), located at a distance of $30 \mathrm{~m}$ from each plot border, represented the centre of just as many circular sampling subplots (total area of about $150 \mathrm{~m}^{2}$ ), where surveys on regeneration by tree species, shrub layer, and litter were also performed. For regeneration layer, seedlings and saplings of tree species with a height between $25 \mathrm{~cm}$ and $130 \mathrm{~cm}$ were considered, regardless of their DBH. In the shrub layer, we measured all the shrub individuals with a height $\geq 25 \mathrm{~cm}$. Due to the peculiar morphological characteristics of the area (nature of the terrain, slope variations, etc.), the total plot area was $10,211 \mathrm{~m}^{2}$ - slightly higher than expected—and the shape slightly irregular rather than being a perfect circle.

\subsection{Field Surveys}

Deadwood was investigated before living biomass to avoid alteration of its size, shape, and natural distribution on the forest floor. However, it seems appropriate to first describe the parameters concerning the living biomass. Both living and dead elements were described in the field with following information: species identity (where possible for dead elements), diameter at breast height (DBH) (all the living trees with $\mathrm{DBH}>2.5 \mathrm{~cm}$ and all the dead elements with $\mathrm{DBH} \geq 5 \mathrm{~cm}$ ), height or length $(\mathrm{m})$, and topographic position in terms of distance to the nearest reference point $(\mathrm{m})$ and azimuth (degrees). Although the legacy of past coppicing is still apparent, in most cases old stumps 
are no longer recognisable and coppice shoots are old enough to develop as single trees. Hence, individuals originating from seeds and shoots were analysed together, except where otherwise stated.

The distances and orientations were measured from the woody fragment of larger size $\left(D_{\max }\right)$ in the case of lying deadwood or from the base of the tree with respect to the other inventory categories. Then, the basal area $\left(\mathrm{m}^{2}\right.$ ha $\left.{ }^{-1}\right)$, average diameter $\left(D_{m}\right.$, calculated with the following formula: $\left.\sqrt{\frac{4 \times G}{\pi \times N}}\right)$, average height $\left(\mathrm{H}_{\mathrm{m}}\right)$ (i.e., the height of the tree with average basal area as observed on a hypsometric curve, that put in relation DBH and height for each tree species), and volume $\left(\mathrm{m}^{3} \mathrm{ha}^{-1}\right)$ were calculated. The distribution diameter of each inventory category was also performed.

Total deadwood was distinguished into standing deadwood, including standing dead trees (SDT), snags (SN), stumps (ST) and dead coppice shoots on living stumps (DCS), and lying deadwood, including lying dead trees or logs (LDT) and coarse woody debris (CWD) (Table 1). SDT and SN were dead trees higher than $130 \mathrm{~cm}$ with an intact or broken stem, respectively, whereas ST were lower than $130 \mathrm{~cm}$. We also assessed the contribution of coarse deadwood, including all dead elements larger than $30 \mathrm{~cm}$, due to its recognised ecological importance for biological diversity [38].

Table 1. Size thresholds and collected attributes of the deadwood categories.

\begin{tabular}{lcc}
\hline \multicolumn{1}{c}{ Deadwood Category } & Size Threshold $(\mathbf{c m})$ & Collected Attribute \\
\hline Standing Deadwood & $\mathrm{H} \geq 130$ & \\
Standing Dead Trees (SDT) & $\mathrm{H} \geq 130$ & $\mathrm{D}_{1.30 \mathrm{~m}}$ \\
Snags (SN) & $\mathrm{H} \geq 100$ & $\mathrm{D}_{\text {base }}, \mathrm{D}_{\text {top }}$ \\
Dead Coppice Shoots (DCS) & $\mathrm{H}<130$ & $\mathrm{D}_{1.30 \mathrm{~m}}$ \\
Stumps (ST) & & $\mathrm{D}_{\text {base, }}, \mathrm{D}_{\text {top }}$, origin (natural or artificial) \\
\hline Lying Deadwood & $\mathrm{L} \geq 130$ & \\
Lying Dead Trees (LDT) & $\mathrm{L} \geq 100$ & $\mathrm{D}_{1.30 \mathrm{~m}}$ length \\
Coarse Woody Debris (CWD) & $\mathrm{D}_{\text {min }}, \mathrm{D}_{\max }$ \\
\hline
\end{tabular}

H: height; L: length. Orientation and position were considered for all the elements.

The volume of snags, coarse woody debris, and stumps was calculated with the following formula (adopted in the protocol of the PRIN 2007 project):

$$
V=\pi \times h / 3 \times\left[R^{2}+r^{2}+(R \times r)\right]
$$

where $V$ is the volume $\left(\mathrm{m}^{3} \mathrm{ha}^{-1}\right), h$ is the height/length $(\mathrm{m}), R$ is the major radius $(\mathrm{m})$ and $r$ is the minor radius $(\mathrm{m})$.

The volume of whole trees, living or dead, was calculated using the double-entry tree volume tables as developed by Tabacchi et al. [39], and built within the National Inventory of Forests and Carbon Sinks [40]. For the other tree species, for which specific formulas have not developed yet, the formulas developed on Ulmus minor Mill. (Field elm) were considered. Decay stage was visually assessed for each dead element following the classification proposed by Hunter [41], which is based on wood surface aspect and bark structure as well as on the presence of evident wood alterations (e.g., wood cavities, hollows, broken branches, etc.) and microorganisms (e.g., fungal mycelium).

\section{Results}

\subsection{Living Biomass (Dendrometric and Structure Data)}

As regards the whole forest stand, living stem density reached 402.4 per hectare; total living volume, including coppice shoots, reached $363.8 \mathrm{~m}^{3} \mathrm{ha}^{-1}$, whereas total basal area was $34.4 \mathrm{~m}^{2} \mathrm{ha}^{-1}$ (Table 2). Stand density of living and dead elements was 631.5 stems per hectare. Among living elements, 33.3 living stumps per hectare (a total of 96.9 living shoots, 2.9 shoot per stump) were also found, corresponding to about one quarter of the total stems, mostly belonging to Quercus ilex $(47.5 \%)$ and Acer campestre (35.4\%). Overall, living tree density was 338.7 per hectare. In terms of 
living stem density, the most common woody species was Quercus pubescens (44.3\%), followed by Quercus ilex (28.2\%), and Acer campestre (19.5\%). Some Castanea sativa individuals also occurred (1.9\%). Some other woody species of particular scientific and/or ecological interest were also present, such as Pyrus pyraster (L.) Burgsd. (European wild pear), Crataegus monogyna Jacq. (Common hawthorn), Mespilus germanica, Malus sylvestris (L.) Mill. (European wild apple), Fraxinus ornus, Prunus spinosa L. (Blackthorn), and Ulmus minor. All together they accounted for $6.1 \%$ of the total number of living stems, corresponding to less than $1 \%$ and $2 \%$ of volume and basal area, respectively. Quercus pubescens was by far the dominant tree species, both in terms of stem density, basal area, and volume, representing about $44 \%$, and more than $80 \%$ and $70 \%$ of the whole stand values, respectively (Table 2 ). Accordingly, both mean diameter and height were also clearly higher in Quercus pubescens than in the other tree species, reaching, for instance, almost double values than Quercus ilex individuals. Quercus ilex stem density was higher than Acer campestre, but being that this species was represented by smaller individuals, it reached lower values of basal area and volume, with the latter being approximately half of the Acer campestre value. Castanea sativa individuals represented only about $3 \%$ of total volume and basal area.

Table 2. Density, diameter, height, volume and basal area of the woody species surveyed.

\begin{tabular}{|c|c|c|c|c|c|c|c|c|}
\hline \multirow{2}{*}{ Species } & \multicolumn{2}{|c|}{ Tree Density } & \multirow{2}{*}{$\frac{\text { Mean Diameter }}{\mathrm{cm}}$} & \multirow{2}{*}{$\frac{\text { Mean Height }}{\mathrm{m}}$} & \multicolumn{2}{|c|}{ Volume } & \multicolumn{2}{|c|}{ Basal Area } \\
\hline & $\mathrm{Nha}^{-1}$ & $\%$ & & & $\mathrm{~m}^{3} \mathrm{ha}^{-1}$ & $\%$ & $\mathrm{~m}^{2} \mathrm{ha}^{-1}$ & $\%$ \\
\hline Quercus pubescens & 178.2 & 44.3 & $42.0 \pm 13.1$ & $19.9 \pm 5.9$ & 297.38 & 81.7 & 24.75 & 71.9 \\
\hline Acer campestre & 78.3 & 19.5 & $28.0 \pm 15.2$ & $12.9 \pm 4.2$ & 35.07 & 9.6 & 4.84 & 14.1 \\
\hline Castanea sativa & 7.8 & 1.9 & $43.3 \pm 8.6$ & $18.7 \pm 5.1$ & 10.59 & 2.9 & 1.19 & 3.5 \\
\hline Other woody species & 24.5 & 6.1 & $15.0 \pm 7.7$ & $6.0 \pm 2.2$ & 1.79 & 0.5 & 0.54 & 1.6 \\
\hline
\end{tabular}

Means are followed by \pm standard deviation (St. Dev.)

Diameter frequency distribution of the forest stand fitted well with a fourth-degree polynomial distribution with a typical rotated-sigmoid shape (Figure 3). Both are considered characteristic trends of diameter distribution of mature or old-growth forests [42,43].

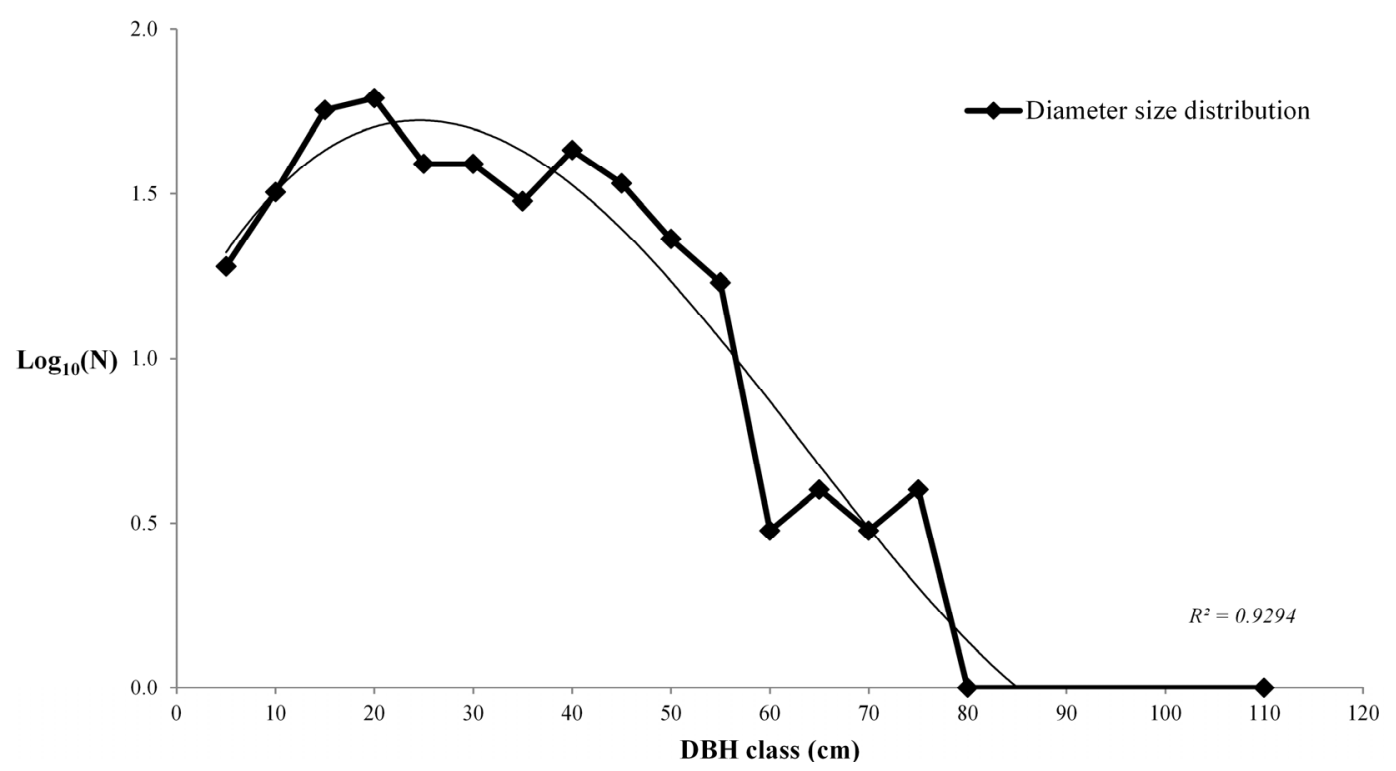

Figure 3. Diameter frequency distribution of all the living stems.

More than $50 \%$ of total volume and basal area was among 40 and $55 \mathrm{~cm} \mathrm{DBH}$ classes (Figure 4). About $4 \%$ and $8 \%$ of volume and basal area, respectively, fell in the DBH classes lower than $20 \mathrm{~cm}$. Interestingly, almost one quarter of the total volume fell within DBH classes higher than $60 \mathrm{~cm}$, 
including the largest trees. Overall, volume was slightly shifted towards the highest DBH classes with respect to basal area, and vice versa.

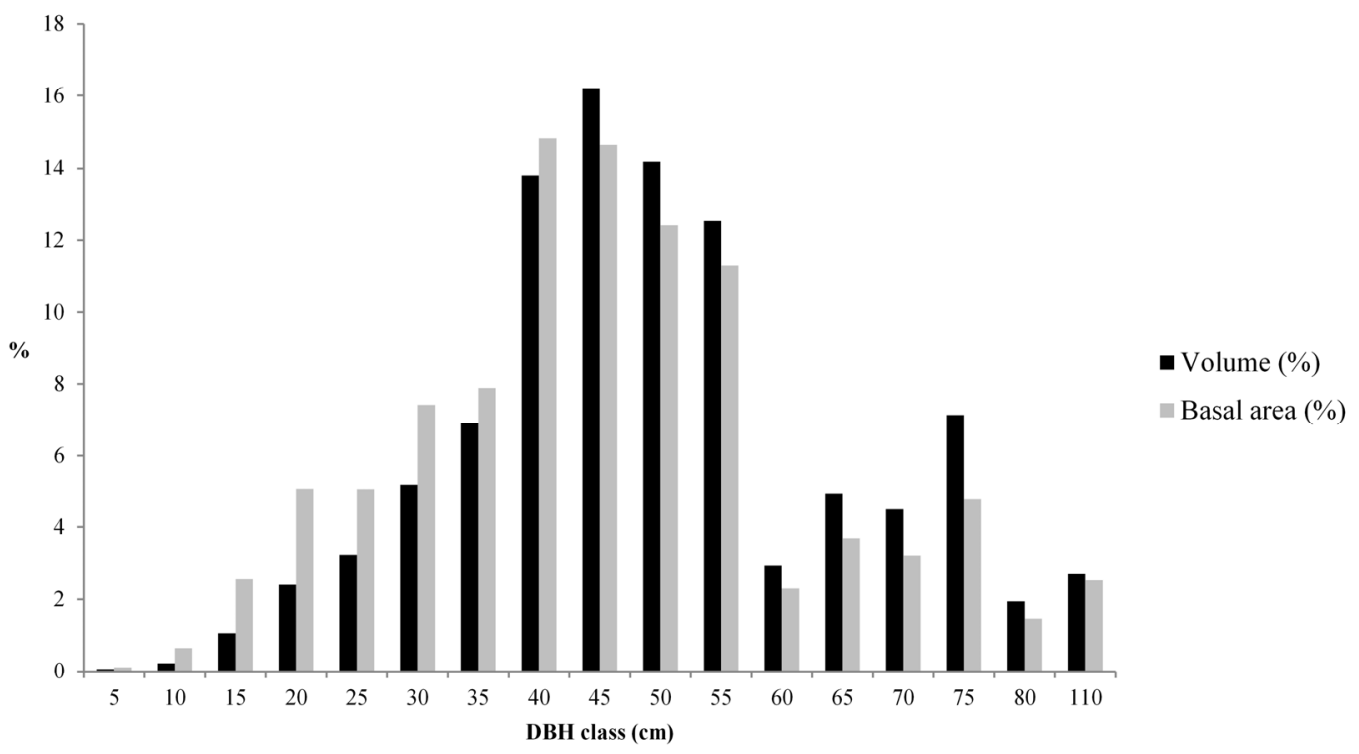

Figure 4. Volume and basal area percentage distribution in DBH classes of all the living stems.

Considerable differences in the relative contribution to volume and basal area of largest stems by each tree species were found. Quercus pubescens made a major contribution, whereas Quercus ilex played a quite minor role in that respect (Figure 5). Almost $80 \%$ and $50 \%$ of total Quercus pubescens volume came from stems with DBH higher than $40 \mathrm{~cm}$, and higher than $50 \mathrm{~cm}$, respectively. Also, more than $40 \%$ of Quercus pubescens and more than $50 \%$ of Acer campestre total volumes were represented by stem diameters larger than $50 \mathrm{~cm}$.

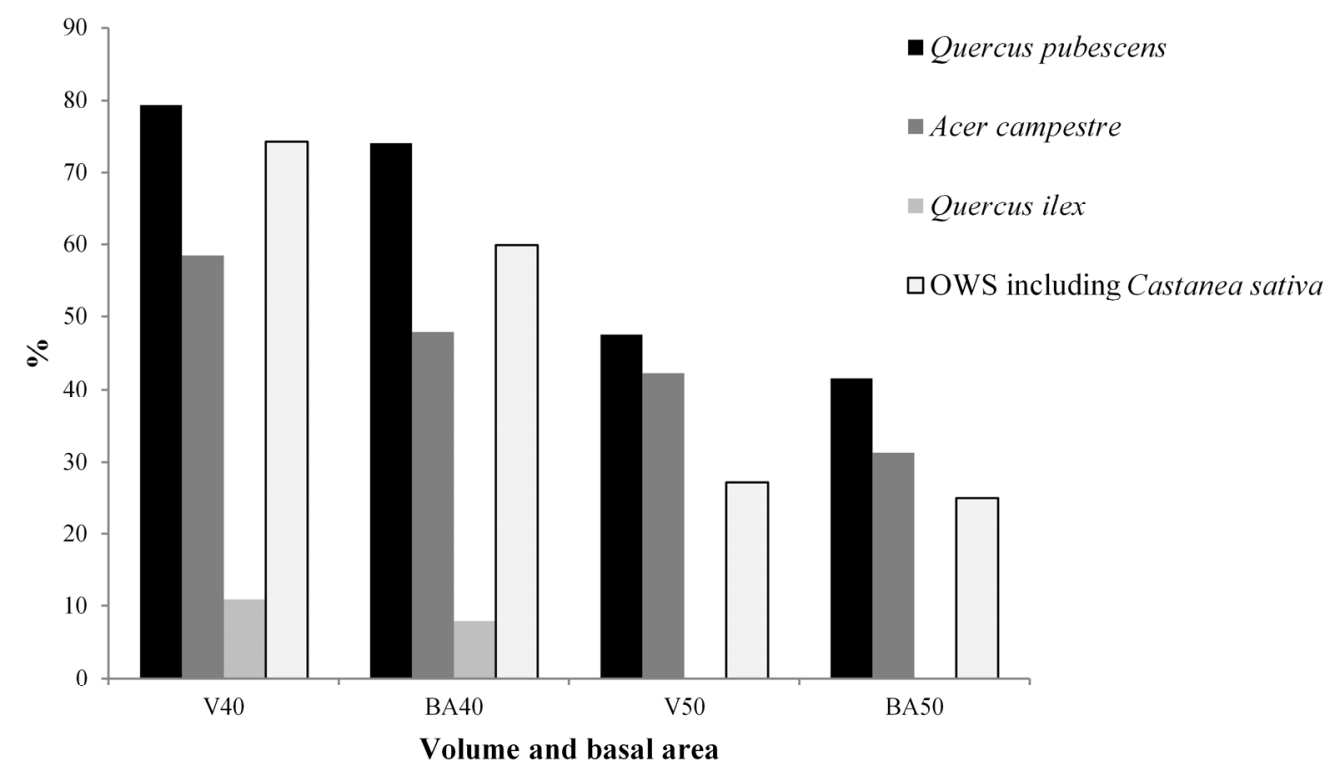

Figure 5. Percentage allocation (\%) of volume (V) and basal area (BA) in the largest trees sorted by tree species. The numbers 40 and 50 after $\mathrm{V}$ and BA refer to stems with DBH equal to or larger than 40 and $50 \mathrm{~cm}$, respectively. 
The highest stem mortality was found in the 10 and $15 \mathrm{~cm} \mathrm{DBH}$ classes (Figure 6). This parameter displayed fluctuating values among DBH classes, but mortality occurred only in the DBH classes lower than $50 \mathrm{~cm}$. On average, stem mortality was about $8 \%$ of the total living stems.

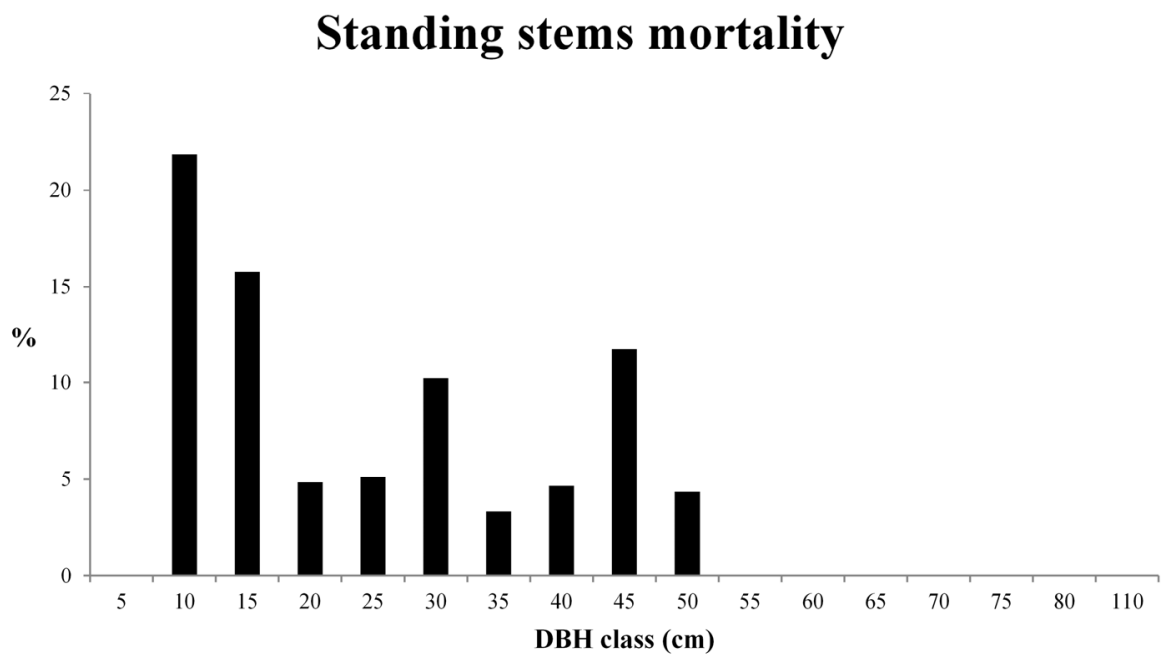

Figure 6. Stem mortality sorted by diameter class.

\subsection{Deadwood Characterisation}

Overall, total deadwood was equal to $32.9 \mathrm{~m}^{3} \mathrm{ha}^{-1}$ and was formed by some 229 elements per hectare (Table 3). As living volume is $363.9 \mathrm{~m}^{3} \mathrm{ha}^{-1}$, dead to live wood ratio is $9 \%$. More than $80 \%$ of deadwood was lying on the ground, predominantly composed by CWD in terms of density and by LDT in terms of volume (Table 3).

Table 3. Total number and volume of deadwood categories.

\begin{tabular}{lcccc}
\hline \multirow{2}{*}{ Deadwood Category } & \multicolumn{2}{c}{ Density } & \multicolumn{2}{c}{ Volume } \\
\cline { 2 - 5 } & $\mathbf{N ~ h a}^{-\mathbf{1}}$ & $\mathbf{\%}$ & $\mathbf{m}^{\mathbf{3}} \mathbf{h a}^{\mathbf{- 1}}$ & $\mathbf{\%}$ \\
\hline Standing deadwood & & & & \\
Standing Dead Trees (SDT) & 14.7 & $45.5(6.4)$ & 4.3 & $79.6(13.1)$ \\
Snags (SN) & 7.8 & $24.1(3.4)$ & 0.6 & $11.1(1.8)$ \\
Dead Coppice Shoots (DCS) & 3.9 & $12.1(1.7)$ & 0.3 & $5.6(0.9)$ \\
Stumps (ST) & 5.9 & $18.3(2.6)$ & 0.2 & $3.7(0.6)$ \\
Total & 32.3 & $100(14.1)$ & 5.4 & $100(16.4)$ \\
\hline Lying deadwood & & & & \\
Lying Dead Trees (LDT) & 66.6 & $33.8(29.1)$ & 22.4 & $81.5(68.1)$ \\
Coarse Woody Debris (CWD) & 130.2 & $66.2(56.8)$ & 5.1 & $18.5(15.5)$ \\
Total & 196.8 & $100(85.9)$ & 27.5 & $100(83.6)$ \\
\hline Total deadwood & 229.1 & & 32.9 & \\
\hline
\end{tabular}

Within round brackets is the percentage with respect to total deadwood.

Standing deadwood, accounting for about $16 \%$ of total deadwood volume, was largely composed by SDT, approaching $80 \%$ of the volume. More than half of the SDT volume belonged to trees with a DBH larger than $40 \mathrm{~cm}$. LDT represented the prevailing type of deadwood, accounting for just under $70 \%$ of the total deadwood volume (Figure 7). Slightly more than half of the LDT volume belonged to the medium diameter classes, ranging from 25 to $35 \mathrm{~cm}$. However, about one-third of the volume was from dead trees larger than $40 \mathrm{~cm}$, and more than $11 \%$ from lower diameter classes. Coarse deadwood volume was slightly more than half of the total deadwood volume, whereas large dead elements were about $10 \%$ of the total deadwood (Table 4). CWD was the dominant form of deadwood in the lowest diameter classes, and CWD and LDT were almost equally represented in the diameter class of 
$15 \mathrm{~cm}$. Conversely, LDT were dominant in the larger diameter classes and represented the only type of deadwood for elements larger than $30 \mathrm{~cm}$. Overall, $\mathrm{LDT}_{30}$ were dominant, whereas global $\mathrm{SD}_{30}$ was higher than $20 \%$ of the total coarse deadwood volume.

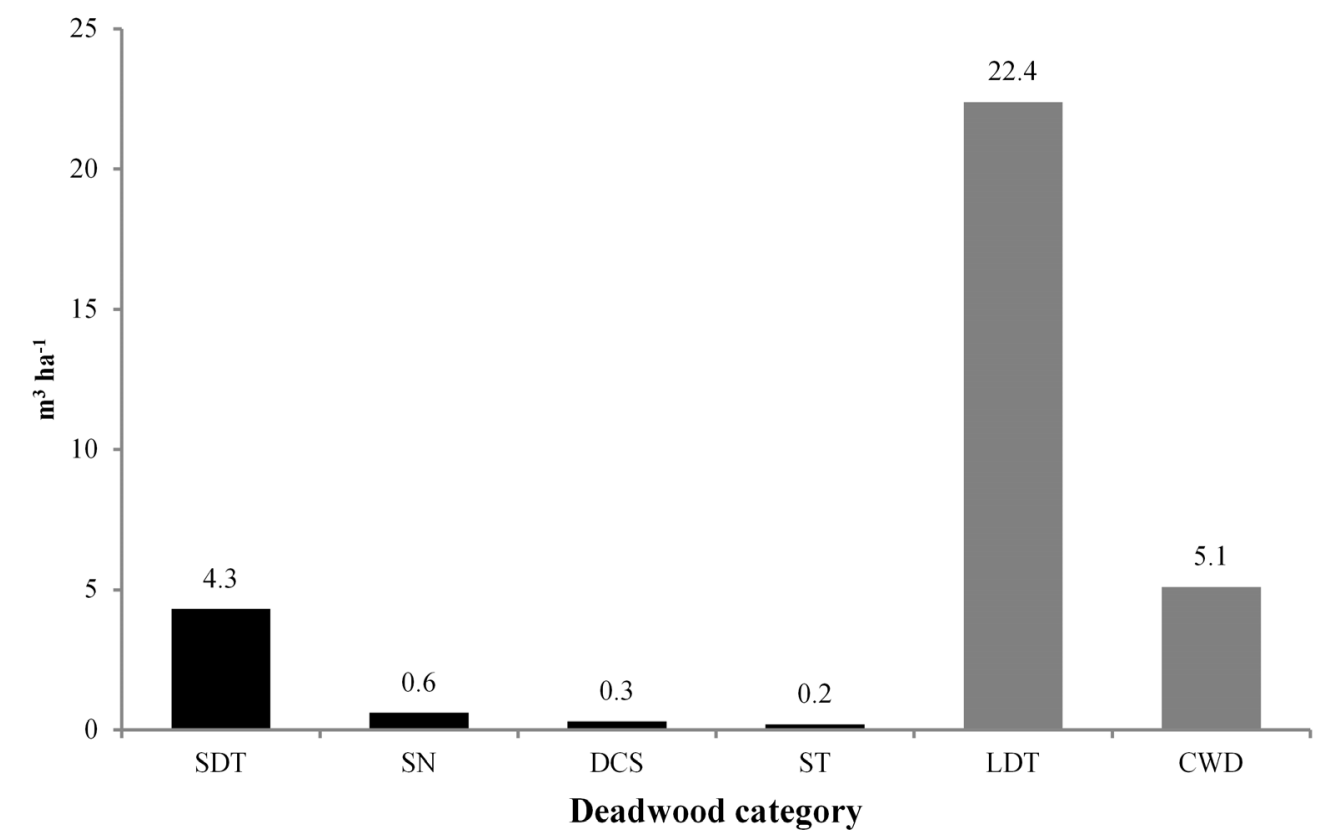

Figure 7. Relative contribution of each deadwood category to total deadwood volume $\left(\mathrm{m}^{3} \mathrm{ha}^{-1}\right)$.

Table 4. Total number and volume of deadwood categories of coarse deadwood (DBH $\geq 30 \mathrm{~cm}$ from Lombardi et al. [38]).

\begin{tabular}{|c|c|c|c|c|}
\hline \multirow{2}{*}{ Deadwood Category } & \multicolumn{2}{|c|}{ Density } & \multicolumn{2}{|c|}{ Volume } \\
\hline & $\mathrm{N} \mathrm{ha}^{-1}$ & $\%$ & $\mathrm{~m}^{3} \mathrm{ha}^{-1}$ & $\%$ \\
\hline \multicolumn{5}{|l|}{ Standing deadwood } \\
\hline Standing Dead Trees $\left(\mathrm{SDT}_{30}\right)$ & 3.9 & 26.7 & 3.2 & $18.4^{\#}\left(74.4^{\S}\right)$ \\
\hline Snags $\left(\mathrm{SN}_{30}\right)$ & 2.0 & 25.0 & 0.5 & $2.9^{\#}(83.3 \S)$ \\
\hline Dead Coppice Shoots $\left(\mathrm{DCS}_{30}\right)$ & - & - & - & - \\
\hline Stumps $\left(\mathrm{ST}_{30}\right)$ & 2.9 & 50.0 & 0.17 & $1.1^{\#}\left(77.3^{\S}\right)$ \\
\hline Total & 8.8 & 27.3 & 3.9 & $22.4^{\#}(72.2 \S)$ \\
\hline \multicolumn{5}{|l|}{ Lying deadwood } \\
\hline Lying Dead Trees $\left(\mathrm{LDT}_{30}\right)$ & 16.6 & 25.0 & 13.5 & $77.6^{\#}(60.3)$ \\
\hline Coarse Woody Debris $\left(\mathrm{CWD}_{30}\right)$ & - & - & - & - \\
\hline Total & 16.6 & 8.5 & 13.5 & $100(77.6)$ \\
\hline Total coarse deadwood & 25.4 & $11.1^{*}$ & 17.4 & $52.9 *$ \\
\hline
\end{tabular}

\#: with respect to total coarse deadwood; $§$ : with respect to total deadwood volume per category; *: with respect to total deadwood.

Diameter frequency distribution of all dead elements of the forest stand, either standing or lying (Figure 8), fitted well with a fourth-degree polynomial distribution with a typical rotated-sigmoid shape. 


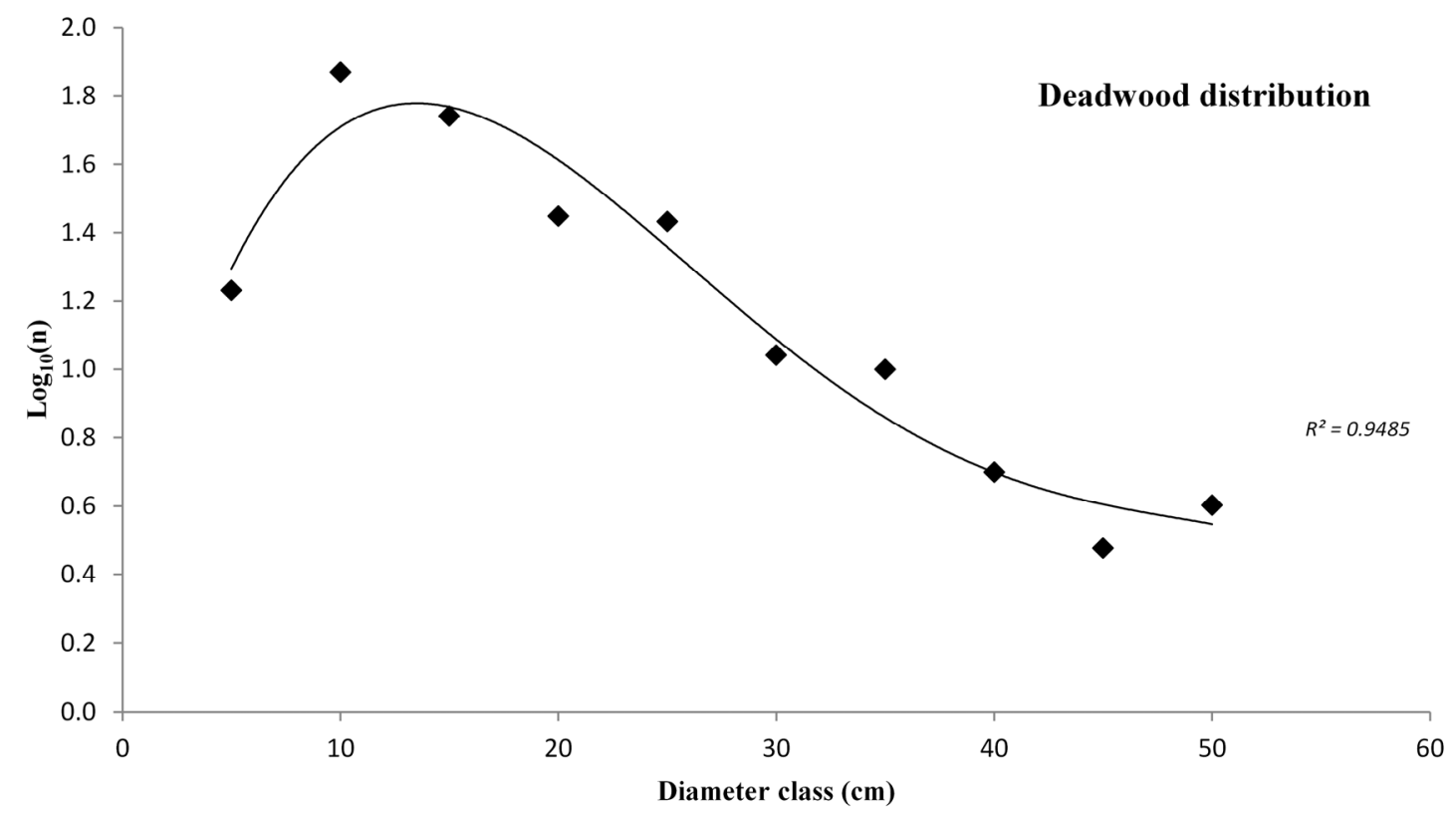

Figure 8. Total deadwood distribution according to mean diameter.

Deadwood was represented in all the diameter classes from $5 \mathrm{~cm}$ to $50 \mathrm{~cm}$, but its volume was not equally distributed among them. Almost half of dead elements were found in the medium diameter classes, between 25 and $35 \mathrm{~cm}$ (Figure 9). Fine $(\mathrm{DBH} \leq 20 \mathrm{~cm}$ ) and coarse $(\mathrm{DBH} \geq 40 \mathrm{~cm}) \mathrm{dead}$ elements were also well-represented, accounting for about one quarter and more than one-third of the total deadwood volume, respectively.

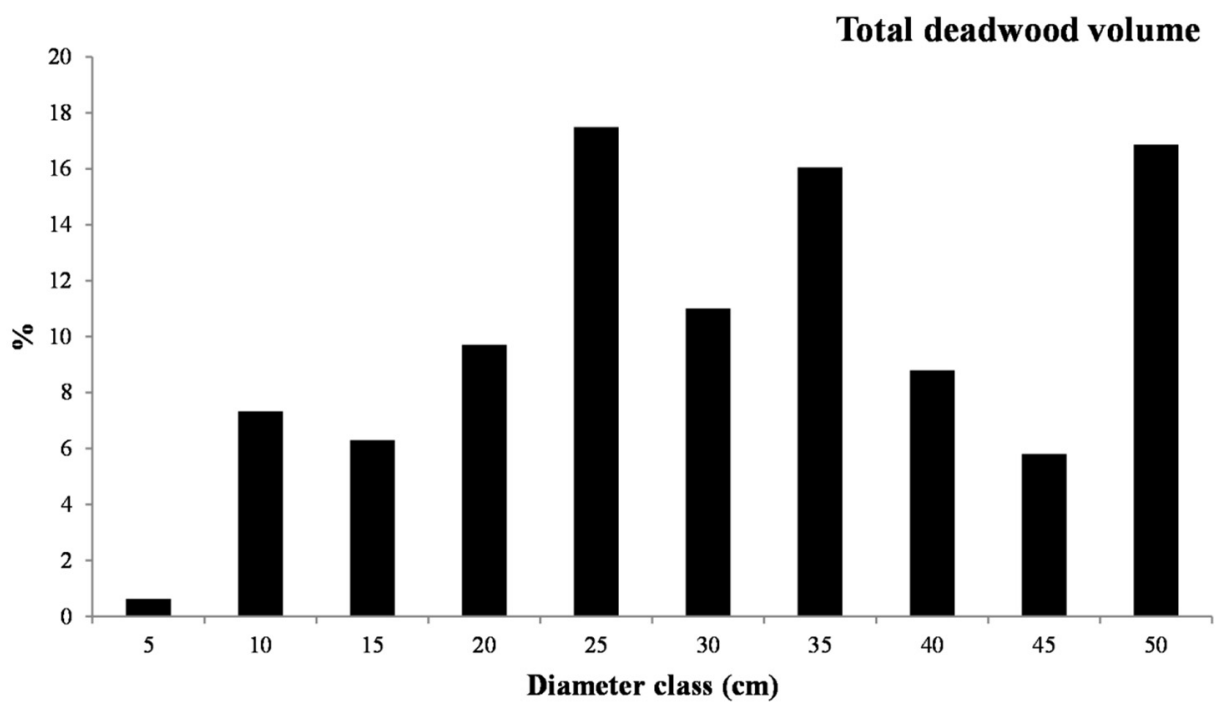

Figure 9. Total deadwood volume percentage distribution according to mean diameter.

Wood decay classes 3 and 4 had the largest share of both standing and lying deadwood (Figure 10). However, standing deadwood was more common than lying deadwood in the first two decay classes, whereas lying was prevalent in the highest three. It is worth highlighting that highly decayed dead elements had the largest share of total and lying deadwood volume. 


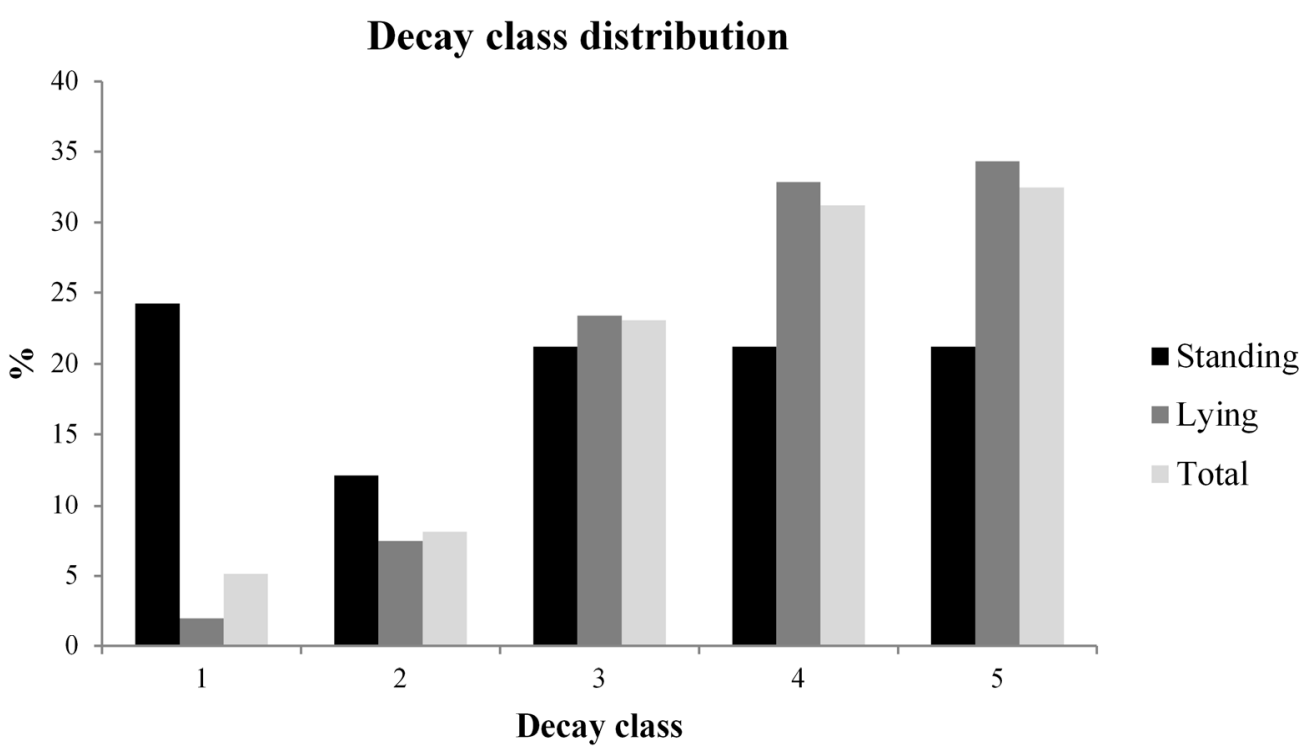

Figure 10. Wood decay classes percentage distribution.

\section{Discussion}

Forests possessing old-growth traits in the Mediterranean Basin are considered to be quite rare and localised, occurring only in restricted areas and under particular environmental and management conditions [44]. However, due to the lack of a shared definition, it is difficult to effectively assess how large is the area covered by such peculiar forest stands. Their expected limited extension is largely a consequence of the historical and widespread alteration processes on a large scale to which forest ecosystems of this biogeographical region have been subject for thousands of years $[45,46]$. However, it is also true that current knowledge, especially for some regions and forest types, is still quite limited and fragmented. This is the case of ageing or old-growth forests dominated by thermophilic oaks such as Quercus ilex and, above all, Quercus pubescens, to which only a handful of studies have been devoted $[47,48]$. It must be stressed that specific information on deadwood amount in mature and/or old-growth Quercus pubescens Mediterranean forests, to the best of our knowledge, is currently not available $[49,50]$; hence this could be the first experimental study carried out in such stands.

Our research allowed us to identify a Mediterranean Quercus pubescens stand (The Fanuso wood) showing a number of old-growth traits, both in living and dead aboveground biomass. In particular, deadwood displayed a number of features that are commonly associated with old-growth Mediterranean forest stands. Total deadwood amount, exceeding $30 \mathrm{~m}^{3} \mathrm{ha}^{-1}$, is particularly relevant. It is higher than the most common threshold considered for the preservation of forest biodiversity, especially the survival of organisms exclusively linked to mature and with low human impact forest habitats [16], such as saproxylic beetles [51]. Such amount is also about 10 times higher than the average for Quercus pubescens and Quercus petraea (Matt.) Liebl. woods of Sicily [52], it is far higher than that of regularly managed forests, and it falls within the mean values found in unmanaged Mediterranean forests [25]. In 21 sites representative of different forest types of Molise region (Italy), deadwood amount ranged from 3.2 to $15.8 \mathrm{~m}^{3} \mathrm{ha}^{-1}$ in regularly managed forests, and from 5.8 to $56.3 \mathrm{~m}^{3} \mathrm{ha}^{-1}$ in forests withdrawn from regular management for about 50 years [53].

Compared to similar Mediterranean deciduous oak forests, deadwood amount is also notably higher than that of Quercus petraea (1-20 $\mathrm{m}^{3} \mathrm{ha}^{-1}$ in Bagnato et al. [54]), Quercus frainetto Ten. (9.3 $\mathrm{m}^{3} \mathrm{ha}^{-1}$ in Barreca et al. [55]), and Quercus cerris stands $\left(15 \mathrm{~m}^{3} \mathrm{ha}^{-1}\right.$ in Marchetti and Lombardi [11]). Conversely, it is within the observed range of another Quercus cerris stand in Tuscany, left unmanaged for about 50 years (22-40 $\mathrm{m}^{3} \mathrm{ha}^{-1}$ in Bertini et al. [24]). Compared to Quercus ilex forest stands, a deadwood amount higher than $30 \mathrm{~m}^{3} \mathrm{ha}^{-1}$ is very close to that recorded in the Gargano wood [49], and it is far higher than that recorded in similar stands in Tuscany, Sardinia, and Lazio 
(Bertini and Fabbio in Bertini et al. [50]). However, Quercus ilex stands may reach much higher values, ranging from 44 to $46 \mathrm{~m}^{3} \mathrm{ha}^{-1}$ ([50,56], Bertini and Fabbio in Bertini et al. [50]), so that $45 \mathrm{~m}^{3} \mathrm{ha}^{-1}$ could be considered a benchmark for thermophilous Mediterranean old-growth forests. By contrast, it is currently quite difficult to define a similar threshold value for Quercus pubescens old-growth forests, due to the lack of reliable data. Italian Fagus sylvatica old-growth forests generally contain a higher deadwood amount than the Fanuso wood, but not in all cases $[23,44]$. Four of these forest stands have a lower amount, and about $60 \%$ of them show a much lower dead to live wood ratio.

An important feature is the relationship between standing and lying components of deadwood, which both play specific and different ecological roles [57]. In Mediterranean oak forests, subject to different forms of management, only 35-44\% of the total deadwood volume is found lying on the forest floor [25,58]. As long as the abandonment of management proceeds, this share tends to progressively increase, until lying deadwood becomes prevalent. A similar trend has been observed both in mesic oaks [24,25] and Fagus sylvatica forests [12,59]. In Europe, this trend seems to be more pronounced in oaks rather than in Fagus sylvatica forests, where, on the contrary, this ratio tends to remain rather constant and lying deadwood always prevalent [60]. It is noteworthy that a multilayered 70-year-old Quercus cerris stand showed a similar value of lying deadwood (84.6\%, [11]) compared to what was found in the present study (i.e., 83.6\%). Furthermore, trees with the smallest diameters $(\mathrm{DBH}<20 \mathrm{~cm})$, are much more common on the ground than in the standing component $(77 \%$ vs. $57 \%)$. On the contrary, trees with $\mathrm{DBH}>40 \mathrm{~cm}$ are more represented in standing than in lying deadwood (18\% vs. 3\%, respectively), as expected in old-growth forests [1].

Compared to other similar Mediterranean forests, the Fanuso wood hosts a relatively high number of standing dead elements, more than 25 per hectare, of which slightly more than half are whole standing trees $[5,25,58]$. However, standing elements with a DBH $>30 \mathrm{~cm}$ are less than four, just close to the lower limit of 5-10 trees per hectare, considered as a reference value for the survival of most saproxylic organisms [61]. Large old trees are a major source of deadwood in the medium- to long-term, firstly as snags when standing and then as logs, thus strongly affecting deadwood dynamics, as well as its availability and supply over time in the ecosystem. This current lack of large standing trees is, however, reasonably expected to be filled in the next decades (i.e., 40-50 years). This should occur as consequence of the progressive natural death of large and old living trees, especially if some natural disturbance event will affect the forest stand. Conversely, a considerable number and volume of lying dead elements was observed, reaching more than 65 elements and more than $20 \mathrm{~m}^{3}$ per hectare, respectively. The first one is higher than the lower limit proposed for deciduous British forests undisturbed by humans by at least 80 years [62]. The number and volume of dead stumps $\left(0.2 \mathrm{~m}^{3} \mathrm{ha}^{-1}\right)$, both very low, indicate the lack of forest utilizations in a long time and they are in line with those of Mediterranean forests left to natural development or unmanaged for decades [49,58].

The distribution of deadwood volume into decay classes provides valuable information on the stage of development reached by the forest stand, and it allows to evaluate indirectly the time elapsed since the last timber harvesting or intense human pressure. In the investigated stand, the co-occurrence of all decay classes, and in particular of the most advanced stage, suggests the availability of many ecological niches and a certain degree of heterogeneity in deadwood. Several saproxylic beetle species are closely related to the more advanced stages of wood degradation [51] and a higher species richness is associated to large-diameter dead fragments, especially in an advanced stage of decay, with respect to smaller ones [63]. Large dead elements, or coarse woody debris, play a key role in the conservation of specific substrate-dependent living organisms and they are one of the more frequently lacking traits in the European forests, as a result of the widespread and intensive utilization to which traditionally-managed forest systems were subject. Accordingly, the saproxylic beetles closely linked to larger dead elements are among the species with a higher extinction risk within European forests [64].

We found decay classes 3 and 4 as dominant. In other unmanaged Mediterranean forests, a lower level of decomposition was detected, with decay classes 2 and 3 being prevalent $[24,49,50]$. In Mediterranean oak forests of the Basilicata region, previously managed and now left to natural 
development [25], the same predominance of classes 3 and 4 was found but they accounted for 39\% of the total deadwood, while in the Fanuso wood they exceeded $60 \%$. The stand has an average tree mortality of standing individuals of $8 \%$, equal to that of Pomieri woods [54] and, close to the threshold of $10 \%$ identified as a reference value in temperate old-growth forests [1]. About $75 \%$ of the standing dead elements belonged to the diameter classes from 10 to $30 \mathrm{~cm}$, while about $15 \%$ were individuals with a $\mathrm{DBH}>40 \mathrm{~cm}$. In other Mediterranean oak forests, mortality was almost exclusively concentrated in the diameter classes lower than $10 \mathrm{~cm}[49,54]$. In the Fanuso wood, within the lowest diameter classes, ranging from 2.5 to $7.5 \mathrm{~cm}$, dead trees are totally absent.

For what concerns living biomass traits, tree density was quite low, slightly higher than 400 stems per hectare. This value falls within the range of an ageing Quercus petraea stand [54] and, more importantly, it is very close to that reported in comparable Mediterranean Quercus ilex and Quercus pubescens forests occurring in Corsica [47] and Sardinia [65], respectively. This parameter is clearly linked to the average size of the plants constituting the dominant forest layer, that is particularly high. Quercus pubescens is the main tree element of the forest stand, having a mean DBH higher than $40 \mathrm{~cm}$, a mean height close to $20 \mathrm{~m}$, and a dominant height higher than 21 meters. A relict Quercus pubescens stand in Gennargentu (Sardinia, Italy) reached dominant heights ranging from 7 to $11 \mathrm{~m}$ [65]. Trees with DBH larger than $50 \mathrm{~cm}$ were 38.2 per hectare $(87 \%$ of which were Quercus pubescens individuals) within the Fanuso wood, a value which is notably higher than the most frequently considered minimum threshold for European and Mediterranean forests, corresponding to at least 30 stems per hectare $[38,66]$. Such value exceeded the benchmark for temperate European old-growth forests [9], it is almost equal to that of other Mediterranean old-growth forests [66], and it is considerably higher than the average recorded in many forest reserves of France, including many oak species [67]. As expected, this value is far lower than the average recorded in Italian old-growth Fagus sylvatica forests, where more than 80 living trees per hectare with DBH larger than $50 \mathrm{~cm}$ are found [38]. However, it is noteworthy that a large proportion of the total living biomass and basal area is concentrated in the highest DBH classes, a typical trait of old-growth forests [1], as large living trees play a key role in the biological and structural diversity of forests. Many birds and insects strongly depend on the presence of a minimum number of large trees for their survival and/or reproduction. In the investigated stand, stems with DBH $>50 \mathrm{~cm}$ accounted for more than $40 \%$ and $35 \%$ of the total volume and basal area, respectively. Also, about $25 \%$ of the total volume is represented by individuals belonging to the $\mathrm{DBH}$ classes $>60 \mathrm{~cm}$, a considerably high value in the context of Mediterranean forests [5]. According to Nilsson et al. [1], in temperate and boreal old-growth forests, trees with DBH $>40 \mathrm{~cm}$ should constitute most of the total volume and basal area of the stand. The Fanuso wood entirely falls within this threshold, as this group of trees accounted for more than $70 \%$ of total volume and more than $60 \%$ of basal area. The abundance of large trees translates into quite high values of volume and basal area. The total living volume, amounting to $363.9 \mathrm{~m}^{3} \mathrm{ha}^{-1}$, is much higher than that of old-growth oak stands from different Italian regions [49,50,68], where it did not exceed $300 \mathrm{~m}^{3} \mathrm{ha}^{-1}$. It is also higher than what was recorded in more mesic Mediterranean forests, characterised by Quercus petraea in Sicily [54] and by Quercus cerris L. (Turkey oak) in Tuscany [24], and in oak stands not managed in more than 170 years [56]. The total basal area, equal to $34.4 \mathrm{~m}^{2} \mathrm{ha}^{-1}$, is almost equal to that of a Quercus ilex stand in Tuscany, withdrawn from forest utilization since about 50 years [68]. Some comparable forest stands exhibited higher values, even higher than $50 \mathrm{~m}^{2} \mathrm{ha}^{-1}[49,50]$. However, a relict Quercus pubescens stand of Sardinia showed just half the basal area of the Fanuso wood, while having very similar values of tree density [65]. The frequency distribution of DBH classes is considered another important diagnostic feature to identify old-growth forests. The distribution of the investigated stand fits well to a polynomial fourth-degree curve and it shows a typical J-reversed shape on a semi-logarithmic scale, indicating a great contribution of large trees [42,43].

Woody species richness recorded in our experimental plot was high compared to other Mediterranean forests [5]. This result significantly enhances the ecological value and the conservation interest of the Fanuso wood, and it highlights the need to ensure adequate long-term protection. 
Eleven different tree species were inventoried during field surveys and other important woody species, such as Sorbus torminalis, were present in the regeneration layer. Although they represent only a small share of the total living biomass, such species play an important ecological role, enriching the trophic chains and providing food to birdlife or small mammals, structurally and biologically diversifying the forest stand. Among them, species such as Ulmus minor and Mespilus germanica are considered of particular interest in Sicily [69]. Such a biological richness may be partly explained by the co-occurrence of two different Mediterranean oak forests, dominated by evergreen Quercus ilex and deciduous Quercus pubescens, and by the absence of forest management since about 50 years.

Deadwood may play an effective role for ecosystem functioning and for biodiversity conservation only if it represents a non-negligible share of the overall aboveground biomass. Thus, it is important to know the relationship between living and dead elements. Despite its high variability, the dead to live wood ratio tends to increase as soon as human pressure on the forest is reduced and it is therefore an important indicator of the maturation of a forest system under the prevailing drive of natural factors. For instance, in mature Quercus cerris stands left to natural development for about 50 years [24], a gradual increase of the dead to live wood ratio, reaching the critical threshold of $10 \%$ [59], was observed.

Based on the results of our field survey, we think that the Fanuso wood should be considered at least as a potentially old-growth Mediterranean forest stand. As far as deadwood traits are concerned, Lombardi et al. [59] have proposed to consider three main aspects for the identification of Mediterranean old-growth forests:

- $\quad$ Dead to live wood ratio should approach $10 \%$;

- $\quad$ Lying deadwood should be prevalent;

- $\quad$ There should be a good diversification of deadwood both in terms of size and decay classes.

The Fanuso wood appears to meet all three criteria. To further corroborate our statement, comparing our field data with a recent review about old-growth temperate forests ([9]; Table 5), it can be observed that only the total amount of deadwood currently does not fall within the range of the considered values.

Table 5. Comparison between the mean values recorded in a recent review about old-growth temperate forests and the values of the investigated forest stand.

\begin{tabular}{ccc}
\hline Parameter & Range $^{1}$ & The Fanuso Wood \\
\hline Dead to live wood ratio (\%) & $9-89$ & $\mathbf{9}$ \\
Basal area $\left(\mathrm{m}^{2} \mathrm{ha}^{-1}\right)$ & $24-57$ & $\mathbf{3 4 . 4}$ \\
Stem density $\left(\mathrm{N} \mathrm{ha}^{-1}\right)$ & $124-1835$ & $\mathbf{4 0 2 . 4}$ \\
Large living trees ${ }^{*}\left(\mathrm{~N} \mathrm{ha}^{-1}\right)$ & $36.5-122$ & $\mathbf{3 8 . 2}$ \\
Living aboveground biomass $\left(\mathrm{m}^{3} \mathrm{ha}^{-1}\right)$ & $255.5-510$ & $\mathbf{3 6 3 . 9}$ \\
Quadratic mean diameter $(\mathrm{cm})$ & $14.6-64.3$ & $\mathbf{3 3 . 0}$ \\
Coarse woody debris $\left(\mathrm{m}^{3} \mathrm{ha}^{-1}\right)$ & $45-469$ & 32.9 \\
\hline rrascano et al. [9]; ${ }^{*}$ : with $\mathrm{DBH}>50 \mathrm{~cm}$. In bold the values falling within the range reported.
\end{tabular}

\section{Conclusions}

The near 50-year absence of regular forest utilizations has allowed the Fanuso wood to develop structures and traits typical of Mediterranean old-growth forests, especially concerning dead elements. Deadwood amount, exceeding the threshold of $30 \mathrm{~m}^{3} \mathrm{ha}^{-1}$, is particularly high in the context of Mediterranean oak forests, and it is one of the highest values so far recorded in Sicilian forests. Also, dead to live wood ratio (9\%) is close to the reference value for Mediterranean old-growth forests (10\%) and lying deadwood was found to be prevalent. There is still a limited contribution of large standing dead trees, but they are expected to increase in the next $40-50$ years. The total living volume is also quite high $\left(>360 \mathrm{~m}^{3} \mathrm{ha}^{-1}\right)$ as it is higher than that of old-growth Italian oak stands. Furthermore, almost $25 \%$ of the total volume is found in $\mathrm{DBH}$ classes higher than $60 \mathrm{~cm}$, including the largest trees. 
However, it is quite difficult to predict how such a forest stand will really change over time. The main future drivers of stand dynamics, that will also affect deadwood components, are the protection regime to which this forest will be subject, and the occurrence of natural and/or anthropogenic disturbance events, including logging.

In the light of the results of our field survey, we recommend the adoption of specific protection measures and management options aimed at maintaining deadwood level, and favoring its increase, and addressed to preserve biodiversity and the peculiar traits of the investigated forest stand. To ensure the long-term preservation of this peculiar Mediterranean Quercus pubescens forest, the following management options are proposed:

- Completely fence off the study area, at least the inner and more preserved area, in order to protect it from livestock grazing, enhancing the chance of seedling establishment by native tree species and also reducing soil erosion processes. Such a restriction measure appears to be urgently needed because abusive grazing still occurs in the Nature Reserve [70];

- Preserve the remnant nuclei of other woody species, different from the dominant tree species, which significantly contribute to the biological and structural diversification of the forest stand;

- Deepen the overall knowledge of the forest ecosystem, including ad hoc investigations of all the biological communities (animals, plants, insects, and fungi) and their competitive and symbiotic relationships, including the role of seed dispersers, mycorrhizae, phytopathogens, etc. [71];

- Establish a permanent monitoring area in which to assess the natural dynamics of deadwood and woody vegetation in a Mediterranean forest stand left unmanaged for about 50 years. It could be known, for instance, the average annual accumulation rate of deadwood [60], the average time needed for the transition from standing to lying on the ground deadwood [72], or the mean degradation time of Quercus spp. wood in similar Mediterranean ecological contexts [73].

The increased and deepened knowledge about Mediterranean old-growth oak forests should help develop specific guidelines regarding the identification and characterisation of such forest ecosystems, which have particular ecological and conservation value. This paper provides a small contribution to that desirable goal.

Acknowledgments: This research was carried out within the PRIN2012 "IDEM" (Development of innovative methods for forest ecosystems monitoring based on remote sensing; Grant 2012EWEY2S, national coordinator: G. Chirici), and the PRIN2010-11 “CARBOTREES" (Climate change mitigation strategies in tree crops and forestry in Italy, national coordinator: R. Valentini), both funded by the Italian Ministry of Education, University and Research. We are particularly grateful to Simone Di Prima and Giovanna Sala for their valuable support during field surveys. Special thanks are due to Giovanni Giardina for his useful suggestions and kindly support for the choice of the study area and to Ivan Buscemi and Sebastiano Sferlazza for their valuable help for the preparation of figures.

Author Contributions: E.B., T.L.M. and D.S.L.M.V. conceived and designed the study, carried out field work, analyzed data and prepared the manuscript. G.L.M. and A.C. carried out field work and analyzed data.

Conflicts of Interest: The authors declare no conflict of interest.

\section{References}

1. Nilsson, S.G.; Niklasson, M.; Hedin, J.; Aronsson, G.; Gutowski, J.M.; Linder, P.; Ljungberg, H.; Mikusìnski, G.; Ranius, T. Densities of large and dead trees in old-growth temperate and boreal forests. For. Ecol. Manag. 2002, 161, 189-204. [CrossRef]

2. Forest Europe. State of Europe's Forests 2015. Available online: http://www.foresteurope.org/docs/ fullsoef2015.pdf (accessed on 20 February 2017).

3. Park, P.S.; Oliver, C.D. Variability of stand structures and development in old-growth forests in the Pacific Northwest, USA. Forests 2015, 6, 3177-3196. [CrossRef]

4. Hilbert, J.; Wiensczyk, A. Old-growth definitions and management: A literature review. BC J. Ecosyst. Manag. $2007,8,15-31$. 
5. Torras, O.; Saura, S. Effects of silvicultural treatments on forest biodiversity indicators in the Mediterranean. For. Ecol. Manag. 2008, 255, 3322-3330. [CrossRef]

6. Spies, T.A. Ecological concepts and diversity of old-growth forests. J. For. 2004, 102, 14-20.

7. Luyssaert, S.; Schulze, E.D.; Börner, A.; Knohl, A.; Hessenmöller, D.; Law, B.E.; Ciais, P.; Grace, J. Old-growth forests as global carbon sinks. Nature 2008, 455, 211-213. [CrossRef] [PubMed]

8. IPCC (Intergovernmental Panel on Climate Change). Good Practice Guidance for Land Use, Land-Use Change and Forestry; IPCC National Greenhouse Gas Inventories Programme: Hayama, Japan, 2003; pp. 1-590.

9. Burrascano, S.; Keeton, W.S.; Sabatini, F.M.; Blasi, C. Commonality and variability in the structural attributes of moist temperate old-growth forests: A global review. For. Ecol. Manag. 2013, 291, 458-479. [CrossRef]

10. Green, P.; Peterken, G.F. Variation in the amount of dead wood in the woodlands of the Lower Wye Valley UK, in the relation to the intensity of management. For. Ecol. Manag. 1997, 98, 229-238. [CrossRef]

11. Marchetti, M.; Lombardi, F. Analisi quali-quantitativa del legno morto in un soprassuolo non gestito: Il caso "Bosco Pennataro", Alto Molise. L'Italia For. Mont. 2006, 275-302. [CrossRef]

12. Christensen, M.; Hahn, K.; Mountford, E.P.; Odor, P.; Standovar, T.; Rozenbergar, D.; Diaci, J.; Wijdeven, S.; Mayer, P.; Winter, S.; et al. Dead wood in European beech (Fagus sylvatica) forest reserves. For. Ecol. Manag. 2005, 210, 267-282. [CrossRef]

13. Lassauce, A.; Paillet, Y.; Jactel, H.; Bouget, C. Deadwood as a surrogate for forest biodiversity: Meta-analysis of correlations between deadwood volume and species richness of saproxylic organisms. Ecol. Indic. 2011, 11, 1027-1039. [CrossRef]

14. Ryberg, N.; Götmark, F.; Olausson, B. Relative importance of coarse and fine woody debris for the diversity of wood-inhabiting fungi in temperate broadleaf forests. Biol. Conserv. 2004, 117, 1-10.

15. La Mantia, T.; Spoto, M.; Massa, B. The colonisation of the Great Spotted Woodpecker (Picoides major L.) in Eucalypt woods and popular cultivations in Sicily. Ecol. Mediterr. 2002, 28, 65-73.

16. Müller, J.; Bütler, R. A review of habitat thresholds for dead wood: A baseline for management recommendations. Eur. J. For. Res. 2010, 129, 981-992. [CrossRef]

17. Müller, J.; Hothorn, T.; Pretzsch, H. Long-term effects of logging intensity on structures, birds, saproxylic beetles and wood-inhabiting fungi in stands of European beech Fagus sylvatica L. For. Ecol. Manag. 2007, 242, 297-305. [CrossRef]

18. Nilsson, S.G. Effect of forest management on the breeding bird community in southern Sweden. Biol. Conserv. 1979, 16, 135-143. [CrossRef]

19. La Mantia, T.; Lo Duca, R.; Massa, B.; Nocentini, S.; Rühl, J. La biodiversità dei boschi siciliani. Part I: L'avifauna. L'Italia For. Mont. 2014, 69, 173-193. [CrossRef]

20. Błońska, E.; Kacprzyk, M.; Spólnik, A. Effect of deadwood of different tree species in various stages of decomposition on biochemical soil properties and carbon storage. Ecol. Res. 2017, 32, 193-203. [CrossRef]

21. Pignatti, G.; De Natale, F.; Gasperini, P.; Paletto, A. Il legno morto nei boschi italiani secondo l'Inventario Forestale Nazionale. Forest@ 2009,6,365-375. [CrossRef]

22. MCPFE (Ministerial Conference on the Protection of Forests in Europe). State of Europe's Forests 2007; The MCPFE Report on Sustainable Forest Management in Europe; MCPFE: Warsaw, Poland, 2007; pp. 1-263.

23. Marchetti, M.; Lombardi, F.; Tognetti, R.; Chirici, G. Verso una rete di connessione dei boschi vetusti. Gazz. Ambient. 2012, 3, 39-50.

24. Bertini, G.; Fabbio, G.; Piovosi, M.; Calderisi, M. Densità di biomassa e necromassa legnosa in cedui di cerro in evoluzione naturale in Toscana. Forest@ 2010, 7, 88-103. [CrossRef]

25. Paletto, A.; De Meo, I.; Cantiani, P.; Ferretti, F. Effects of forest management on the amount of deadwood in Mediterranean oak ecosystems. Ann. For. Sci. 2014, 71, 791-800. [CrossRef]

26. Badalamenti, E.; Pasta, S.; La Mantia, T.; La Mela Veca, D.S. Old-growth forests in Mediterranean ecosystems: Preliminary investigations and management proposals in a Sicilian study case. Nat. Areas J. (under review).

27. Rivas-Martínez, S. Global Bioclimatics (Clasificación Bioclimática de la Tierra). Available online: http: //www.globalbioclimatics.org/book/bioc/global_bioclimatics-2008_00.htm (accessed on 20 February 2017).

28. Servizio Idrografico. Bacini Con Foce Al Litorale Della Sicilia. Annali Idrologici, Sezione di Palermo. 2012. Available online: http:/ / www.osservatorioacque.it/dati/ANNALI/annale_2012_parte_I.pdf (accessed on 12 February 2017).

29. Fierotti, G. Carta dei Suoli Della Sicilia (Scala 1:250,000); Regione Siciliana; Assessorato Territorio e Ambiente: Palermo, Italy, 1988. 
30. Gianguzzi, L. Il Paesaggio Vegetale Della Riserva Naturale Orientata "Bosco Della Ficuzza, Rocca Busambra, Bosco del Cappelliere, Gorgo del Drago"; Collana Sicilia Foreste; Regione Siciliana; AFDRS: Palermo, Italy, 2004; Volume 22, pp. 1-160.

31. Sala, G.; Giardina, G.; La Mantia, T. I fattori di rischio per la biodiversità forestale in Sicilia: Il caso studio del cerro di Gussone. L'Italia For. Mont. 2011, 66, 71-80. [CrossRef]

32. Pasta, S.; de Rigo, D.; Caudullo, G. Quercus pubescens in Europe: Distribution, habitat, usage and threats. In European Atlas of Forest Tree Species; San-Miguel-Ayanz, J., de Rigo, D., Caudullo, G., Houston Durrant, T., Mauri, A., Eds.; Publications Office of the European Union: Luxembourg, 2016; pp. 156-157.

33. Gianguzzi, L.; La Mantia, A. Le serie di vegetazione della Riserva Naturale Orientata “Bosco Ficuzza, Rocca Busambra, Bosco del Cappelliere e Gorgo del Drago" con allegata carta della vegetazione (scala 1:20,000). Nat. Sicil 2004, 28, 205-242.

34. Giardina, G.; La Mantia, T.; Sala, G.; Di Leo, C.; Pasta, S. Possibile origine e consistenza di un popolamento di Quercus trojana Webb subsp. trojana (Fagaceae) nel Bosco della Ficuzza (Palermo, Sicilia). Nat. Sicil 2014, 38, 265-289.

35. Giardina, G.; La Mantia, T.; Sala, G.; Pasta, S. Ostrya carpinifolia Scop. (fam. Betulaceae) a Ficuzza (Monti Sicani, provincia di Palermo): Note ecologiche e demografiche. Nat. Sicil 2015, 39, 73-75.

36. Bianchetto, E.; Buscemi, I.; Corona, P.; Giardina, G.; La Mantia, T.; Pasta, S. Fitting the stocking rate with pastoral resources to manage and preserve Mediterranean forestlands: A case study. Sustainability 2015, 7, 7232-7244. [CrossRef]

37. Calamini, G.; Maltoni, A.; Travaglini, D.; Iovino, F.; Nicolaci, A.; Menguzzato, G.; Corona, P.; Ferrari, B.; Di Santo, D.; Chirici, G.; et al. Stand structure attributes in potential old-growth forests in the Apennines, Italy. L'Italia For. Mont. 2011, 66, 365-381. [CrossRef]

38. Lombardi, F.; Marchetti, M.; Corona, P.; Merlini, P.; Chirici, G.; Tognetti, R.; Puletti, N. Quantifying the effect of sampling plot size on the estimation of structural indicators in old-growth forest stands. For. Ecol. Manag. 2015, 346, 89-97. [CrossRef]

39. Tabacchi, G.; Di Cosmo, L.; Gasparini, P.; Morelli, S. Stima del Volume e Della Fitomassa Delle Principali Specie Forestali Italiane. Equazioni di Previsione, Tavole del Volume e Tavole Della Fitomassa Arborea Epigea; Consiglio per la Ricerca e la Sperimentazione in Agricoltura, Unità di Ricerca per il Monitoraggio e la Pianificazione Forestale: Trento, Italy, 2011; pp. 1-412.

40. INFC. Le stime di superficie 2005-Prima parte. In Inventario Nazionale Delle Foreste e dei Serbatoi Forestali di Carbonio, MiPAAF-Corpo Forestale dello Stato; Tabacchi, G., De Natale, F., Di Cosmo, L., Floris, A., Gagliano, C., Gasparini, P., Genchi, L., Scrinzi, G., Tosi, V., Eds.; Ispettorato Generale, CRA-ISAFA: Trento, Italy, 2007.

41. Hunter, M.L., Jr. Wildlife, Forests and Forestry: Principles for Managing Forests for Biological Diversity; Prentice Hall: Englewood Cliffs, NJ, USA, 1990.

42. Chiavetta, U.; Sallustio, L.; Garfi, V.; Maesano, M.; Marchetti, M. Classification of the oldgrowthness of forest inventory plots with dissimilarity metrics in Italian national parks. Eur. J. For. Res. 2012, 131, 1473-1483. [CrossRef]

43. Motta, R.; Garbarino, M.; Berretti, R.; Meloni, F.; Nosenzo, A.; Vacchiano, G. Development of old-growth characteristics in uneven-aged forests of the Italian Alps. Eur. J. For. Res. 2015, 134, 19-31. [CrossRef]

44. Lombardi, F.; Chirici, G.; Marchetti, M.; Tognetti, R.; Lasserre, B.; Corona, P.; Barbati, A.; Ferrari, B.; Di Paolo, S.; Giuliarelli, D.; et al. Deadwood in forest stands close to old-growthness under Mediterranean conditions in the Italian Peninsula. L'Italia For. Mont. 2010, 65, 481-504. [CrossRef]

45. La Mela Veca, D.S.; Cullotta, S.; Sferlazza, S.; Maetzke, F.G. Anthropogenic influences in land use/land cover changes in Mediterranean forest landscapes in Sicily. Land 2016, 5, 3. [CrossRef]

46. Vizzarri, M.; Sallustio, L.; Travaglini, D.; Bottalico, F.; Chirici, G.; Garfi, V.; Lafortezza, R.; La Mela Veca, D.S.; Lombardi, F.; Federico Maetzke, F.; et al. The MIMOSE approach to support sustainable forest management planning at regional scale in Mediterranean contexts. Sustainability 2017, 9, 316. [CrossRef]

47. Richard, F.; Millot, S.; Gardes, M. Diversity and specificity of ectomycorrhizal fungi retrieved from an old-growth Mediterranean forest dominated by Quercus ilex. New Phytol. 2005, 166, 1011-1023. [CrossRef] [PubMed]

48. Scattolin, L.; Lancellotti, E.; Franceschini, A.; Montecchio, L. The ectomycorrhizal community in Mediterranean old-growth Quercus ilex forests along an altitudinal gradient. Plant Biosyst. 2014, 148, 74-82. [CrossRef] 
49. Marziliano, P.A. Analisi quali-quantitativa della necromassa in cedui invecchiati di leccio (Quercus ilex L.) del Gargano. Forest@ 2009, 6, 19-28. [CrossRef]

50. Bertini, G.; Fabbio, G.; Piovosi, M.; Calderisi, M. Densità di biomassa e necromassa legnosa in cedui invecchiati di leccio in Sardegna e di faggio in Toscana. Forest@ 2012, 9, 108-129. [CrossRef]

51. Della Rocca, F.; Stefanelli, S.; Pasquaretta, C.; Campanaro, A.; Bogliani, G. Effect of deadwood management on saproxylic beetle richness in the floodplain forests of northern Italy: Some measures for deadwood sustainable use. J. Insect Conserv. 2014, 18, 121-136. [CrossRef]

52. Hofmann, A.; Cibella, R.; Bertani, R.; Miozzo, M.; Fantoni, I.; Luppi, S. Strumenti Conoscitivi per la Gestione Delle Risorse Forestali Della Sicilia. Sistema Informativo Forestale; Assessorato Territorio e Ambiente Regione Siciliana: Perugia, Italy, 2011; pp. 1-208.

53. Lombardi, F.; Lasserre, B.; Tognetti, R.; Marchetti, M. Deadwood in relation to stand management and forest type in Central Apennines (Molise, Italy). Ecosystems 2008, 11, 882-894. [CrossRef]

54. Bagnato, S.; Merlino, A.; Mercurio, R.; Solano, F.; Scarfò, F.; Spampinato, G. Le basi conoscitive per il restauro forestale: Il caso di Bosco Pomieri (Parco Regionale delle Madonie, Sicilia). Forest@ 2012, 9, 8-19. [CrossRef]

55. Barreca, L.; Cutini, A.; Mercurio, R. Caratterizzazione della necromassa in boschi di farnetto (Quercus frainetto Ten.) della Calabria. Forest@ 2008, 5, 187-194. [CrossRef]

56. Persiani, A.M.; Lombardi, F.; Lunghini, D.; Granito, V.M.; Tognetti, R.; Maggi, O.; Pioli, S.; Marchetti, M. Stand structure and deadwood amount influences saproxylic fungal biodiversity in Mediterranean mountain unmanaged forests. iForest 2015, 9, 115-124. [CrossRef]

57. Nordén, B.; Götmark, F.; Tönnberg, M.; Ryberg, M. Dead wood in semi-natural temperate broadleaved woodland: Contribution of coarse and fine dead wood, attached dead wood and stumps. For. Ecol. Manag. 2004, 194, 235-248. [CrossRef]

58. Paletto, A.; Ferretti, F.; De Meo, I.; Cantiani, P.; Focacci, M. Ecological and environmental role of deadwood in managed and unmanaged forests. In Sustainable Forest Management; Diez, J.J., Ed.; INTECH Open Access Publisher: Rijeka, Croatia, 2012; pp. 219-238.

59. Lombardi, F.; Lasserre, B.; Chirici, G.; Tognetti, R.; Marchetti, M. Deadwood occurrence and forest structure as indicators of old-growth forest conditions in Mediterranean mountainous ecosystems. Ecoscience 2012, 19, 344-355. [CrossRef]

60. Vandekerkhove, K.; De Keersmaeker, L.; Menke, N.; Meyer, P.; Verscheide, P. When nature takes over from man: Dead wood accumulation in previously managed oak and beech woodlands in North-western and Central Europe. For. Ecol. Manag. 2009, 258, 425-435. [CrossRef]

61. Mason, F.; Nardi, G.; Whitmore, D. Recherches sur la restauration des habitats du bois mort: L'exemple du LIFE “Bosco della Fontana” (Italie). In Bois Mort et à Cavités, Une clé Pour Des Forêts Vivantes; Vallauri, D., André, J., Dodelin, B., Eynard-Machet, R., Rambaud, D., Eds.; Éditions Tec \& Doc: Paris, France, 2005; pp. 285-291.

62. Kirby, K.J.; Reid, C.M.; Thomas, R.C.; Goldsmith, F.B. Preliminary estimates of fallen dead wood and standing dead trees in managed and unmanaged forests in Britain. J. Appl. Ecol. 1998, 35, 148-155. [CrossRef]

63. Dittrich, S.; Jacob, M.; Bade, C.; Leuschner, C.; Hauck, M. The significance of deadwood for total bryophyte, lichen, and vascular plant diversity in an old-growth spruce forest. Plant Ecol. 2014, 215, 1123-1137. [CrossRef]

64. Seibold, S.; Brandl, R.; Buse, J.; Hothorn, T.; Schmidl, J.; Thorn, S.; Müller, J. Association of extinction risk of saproxylic beetles with ecological degradation of forests in Europe. Conserv. Biol. 2015, 29, 382-390. [CrossRef] [PubMed]

65. Citterio, G.; Puxeddu, M.; Giannini, R. La foresta relitta di roverella dei Monti del Gennargentu, Sardegna. Forest@ 2007, 4, 11-18. [CrossRef]

66. Tiscar, P.; Lucas-Borja, M. Structure of old-growth and managed stands and growth of old trees in a Mediterranean Pinus nigra forest in southern Spain. Forestry 2016, 89, 201-207. [CrossRef]

67. Paillet, Y.; Pernot, C.; Boulanger, V.; Debaive, N.; Fuhr, M.; Gilg, O.; Gosselin, F. Quantifying the recovery of old-growth attributes in forest reserves: A first reference for France. For. Ecol. Manag. 2015, 346, 51-64. [CrossRef]

68. Bianchi, L.; Brovelli, M.; Maltoni, A.; Calamini, G. Confronto tra metodologie di stima della necromassa legnosa in un ceduo invecchiato di leccio. Forest@ 2013, 10, 34-42. [CrossRef] 
69. La Mantia, T.; Pasta, S. The Sicilian Phanerophytes: Still a Noteworthy Patrimony, Soon a Lost Resource? IUFRO Conference "Monitoring and Indicators of Forest Biodiversity in Europe-From Ideas to Operationality", Firenze, Italy, 15 November 2003.

70. La Mantia, T.; Pasta, S.; Giardina, G.; Marchetti, M. The Effect of Grazing in Forests: The Case Study of Ficuzza (W Sicily). In Proceedings of the International Congress: "Silvopastoralism and Sustainable Management", Lugo, Spain, 18-24 April 2004.

71. La Mantia, T.; Bellavista, M.; Giardina, G.; Sparacio, I. Longhorn beetles of the Ficuzza woods (W Sicily, Italy) and their relationship with plant diversity (Coleoptera, Cerambycidae). Biodivers. J. 2010, 1, 15-44.

72. Corace, R.G., III; Seefelt, N.E.; Goebel, P.C.; Shaw, H.L. Snag longevity and decay class development in a recent jack pine clearcut in Michigan. North. J. Appl. For. 2010, 27, 125-131.

73. Schowalter, T.D.; Zhang, Y.L.; Sabin, T.E. Decomposition and nutrient dynamics of oak Quercus spp. logs after five years of decomposition. Ecography 1998, 21, 3-10. [CrossRef]

(C) 2017 by the authors. Licensee MDPI, Basel, Switzerland. This article is an open access article distributed under the terms and conditions of the Creative Commons Attribution (CC BY) license (http://creativecommons.org/licenses/by/4.0/). 